\title{
KLIENTELISME POLITIK PADA PEMILIHAN GUBERNUR SUMATERA UTARA TAHUN 2018 DI KABUPATEN LABUHANBATU
}

\author{
Iqbal Arif Siregar \\ Jurusan Ilmu Politik, Fisip, Universitas Andalas \\ Email: iqbalarifsiregar@gmail.com
}

\begin{abstract}
Abstrak
Klientelisme politik Pemuda Pancasila Labuhanbatu diperlihatkan dalam bentuk relasi antara anggota Pemuda Pancasila dengan Wakil Bupati Labuhanbatu. Dukungan yang diberikan mulai dari melakukan konsolidasi internal, mobilisasi anggota dan pemilih, pengawalan kampanye yang dilakukan pasangan calon dan partai koalisi kemudian sampai kepada pengawalan TPS pada hari pemilihan berlangsung. Tujuan penelitian ini adalah untuk melihat, mendeskripsikan dan menganalisis praktik klientelisme politik antara wakil bupati Kabupaten Labuhanbatu dengan Pemuda Pancasila dalam upaya pemenangan pasangan calon gubernur Edy Rahmayadi dan Musa Rajekshah pada pemilihan gubernur Sumatera Utara tahun 2018. Metode dalam penelitian ini menggunakan metode kualitatif dengan jenis pendekatan studi kasus. Hasil dari penelitian skripsi ini menjelaskan dan menggambarkan praktik klientelisme yang terjadi dengan adanya pembentukan tim pemenangan internal Pemuda Pancasila yang dibentuk langsung oleh Wakil Bupati selaku Ketua MPC Pemuda Pancasila. Tim pemenangan internal ini berbeda dengan tim pemenangan bentukan partai koalisi, dimana posisi wakil bupati juga sebagai ketua tim pemenangan bentukan partai koalisi. Dalam menjalankan agenda pemenangan, tim pemenangan internal Pemuda Pancasila mendapatkan dana dari pemberian personal wakil bupati. Kemudian pertukaran klientelistik yang didapatkan Pemuda Pancasila adalah pemberian dana hibah yang berasal dari anggaran keuangan daerah, dimana sebelumnya Pemuda Pancasila tidak mendapatkan dana hibah apapun.
\end{abstract}

Kata Kunci: Klientelisme, Pemuda Pancasila, Relasi, Bentuk Pertukaran

\begin{abstract}
Political clientelism of Pemuda Pancasila of Labuhanbatu is shown in the form of relation between the members of Pemuda Pancasila and the deputy regent of Labuhanbatu regency. The support provided starts from conducting an internal, mobilizing members and voters, escorting the campaign carried out by the candidate pairs and supporting coalition party campaigns, then to escorting the TPS on the election day. The purpose of this thesis is to see, describe and analyze the political clientelism practice between the deputy regent of Labuhanbatu regency and Pemuda Pancasila in an effort to win the pair of governor candidates Edy Rahmayadi and Musa Rajekshah in the election of governor of North Sumatra in 2018. The method used in this thesis is qualitative method with the type of case study approach. The results of this thesis explain and illustrate the clientelism practice that occurs with the formation of an internal winning team of Pemuda Pancasila which was formed directly by the deputy regent as the chairman of MPC of Pemuda Pancasila. This internal winning team is different from the winning team that formed by the coalition party, where the position of deputy regent is also the head of the winning team that formed by the coalition party. In running out the agenda of winning team, internal winning team of Pemuda Pancasila received funding from deputy regent as personal gift. Then the clientelistic exchange obtained by Pemuda Pancasila was the provision of grant funds from regional financial budget, where previously Pemuda Pancasila did not get any grant funds.
\end{abstract}

Keywords: Clientelism, Pemuda Pancasila, Relation, Exchange Form 


\section{PENDAhuluan}

Klientelisme merupakan suatu fenomena yang masih melekat dalam praktik demokrasi di Indonesia yang secara khusus lekat dengan konteks elektoral dan kedaerahan. Melihat kembali pada pemikiran mendasarnya, klientelisme sebagai perilaku koruptif dan merupakan bentuk transaksi yang berjalan dua sisi, yaitu supply dan demand. Kemudian adanya demand dari warga atau pemilih merupakan konsekuensi logis dari minimnya kemampuan warga untuk memastikan agenda kesejahteraannya ada dalam agenda politik. ${ }^{1}$ Klientelisme politik terjadi ketika para pemilih, para pegiat kampanye atau aktor-aktor lain menyediakan dukungan elektoral bagi para politisi dengan imbalan berupa bantuan atau manfaat material. Para politisi tersebut menggunakan metode klientelistik untuk memenangkan pemilihan dengan membagi-bagikan bantuan, barang-barang, atau uang tunai kepada para pemilih baik individual maupun kelompok-kelompok kecil. ${ }^{2}$ Dalam salah satu artikelnya, Berenschot ${ }^{3}$ mengkaji dan mendalami indikasi dari seberapa jauh hubungan patron-klien masih menjadi bagian dari dinamika demokrasi di Indonesia, terutama pada tingkat daerah.

Umumnya, klientelisme sering melibatkan jaringan informal yang digambarkan melalui jaringan kekerabatan, relasi keluarga yang dimiliki sebagai sumberdaya dan modal dalam bentuk pemilih, sampai kepada pemanfaatan jaringan organisasi yang memiliki basis massa yang besar. Didalam penelitian ini, peneliti ingin melihat kepada keterlibatan Pemuda Pancasila dalam upaya pemenangan pasangan calon gubernur Sumatera Utara pada tahun 2018. Dimana peran Pemuda Pancasila ini dapat dianalisis melalui praktik klientelisme politik yang melibatkan struktur dan jajaran kepengurusan serta basis massa anggota yang dimiliki Pemuda Pancasila.

Sebagai salah satu ormas terbesar di Sumatera Utara, Pemuda Pancasila (PP) menyatakan dukungan kepada pasangan calon Edy-Musa dalam pilkada Sumut 2018. Dukungan tersebut disampaikan langsung oleh pimpinan Majelis Pengurus Wilayah (MPW) Pemuda Pancasila Sumatera Utara, Khodrat Shah. Menurutnya, Pemuda Pancasila memiliki peran yang signifikan dalam menentukan kemenangan pada pemilihan gubernur Sumatera Utara 2018. Sehingga penting bagi Pemuda Pancasila untuk mengambil momentum menentukan nasib Sumatera Utara melalui kontestasi pemilihan gubernur ini.

\footnotetext{
${ }^{1}$ Nur Ramadhan, M. \& Berlianto, J. D. Klientelisme Sebagai Perilaku Koruptif dan Demokrasi Banal. Jurnal Antikorupsi INTEGRITAS. 2019. 5(1): 2615-7977. 169-180.

${ }^{2}$ Aspinall, E., \& Berenschot, W. 2019. Democracy for Sale: Pemilu, Klientelisme, dan Negara di Indonesia. Jakarta: Yayasan Pustaka Obor Indonesia.

${ }^{3}$ Berenschot, W. The Political Economy of Clientelism: a Comparative Study of Indonesia's Patronage Democracy. Comparative Political Studies. 2018. 51(12), 1563-1593.
} 
Dukungan Pemuda Pancasila kepada pasangan Edy-Musa bukan tanpa alasan. Selain karena sosok Edy Rahmayadi yang dinilai tegas dan mampu merubah Sumatera Utara menjadi lebih sejahtera dan bermartabat, sementara Musa Rajekshah adalah bagian dari keluarga besar Pemuda Pancasila. Walaupun secara kekerabatan, ketua MPW Pemuda Pancasila (Khodrat Shah) dan calon wakil gubernur yang diusung merupakan hubungan paman dan keponakan, tapi secara gamblang dukungan yang diberikan murni atas objektivitas Pemuda Pancasila yang menilai bahwa Musa Rajekshah adalah salah satu kader terbaik dan sedang menduduki jabatan Ketua Bidang Pengusaha Pemuda Pancasila.

Menanggapi instruksi yang diberikan oleh ketua MPW, pengurus Pemuda Pancasila di tingkat kabupaten merespon hal tersebut. Salah satu kabupaten yang memperlihatkan antusiasmenya terhadap instruksi itu adalah pengurus Pemuda Pancasila di kabupaten Labuhanbatu. Hal ini dapat dilihat dari masa-masa saat kampanye yang dilaksanakan. ${ }^{4}$ Sebagian besar peserta kampanye dihadiri oleh kader bahkan partisan Pemuda Pancasila, dan yang paling menonjol yaitu Wakil Bupati Kabupaten Labuhanbatu itu sendiri merupakan ketua Majelis Pengurus Cabang (MPC) Pemuda Pancasila.

Andi Suhaimi selaku wakil bupati sekaligus sebagai Ketua MPC Pemuda Pancasila memberikan dukungan kepada pasangan calon Edy-Musa pada pemilihan Gubernur Sumatera Utara tahun 2018 yang diusung oleh partai Golkar yang juga merupakan partai yang menjadi kendaraan politik beliau menuju jabatan wakil bupati tersebut. Bentuk dukungan Andi Suhaimi terlihat pada mobilisasi dan instruksi yang diberikan kepada pengurus dan kader Pemuda Pancasila di Kabupaten Labuhanbatu dalam upaya memenangkan pasangan calon gubernur yang didukung.

Sebelumnya pada pemilihan bupati dan wakil bupati Kabupaten Labuhanbatu, pasangan Pangonal Harahap dan Andi Suhaimi Dalimunthe memenangkan pemilihan bupati dan wakil bupati Kabupaten Labuhanbatu dengan adanya campur tangan dari Pemuda Pancasila. ${ }^{5}$ Hal ini menjadikan pembuktian bahwa Pemuda Pancasila memiliki andil yang cukup dipertimbangkan dan pusaran politik di daerah tersebut. Kemudian faktor mobilisasi yang dilakukan kader-kader Pemuda Pancasila juga sangat berpengaruh besar dengan cara soft campaign dikalangan masyarakat.

\footnotetext{
${ }^{4} \mathrm{Hal}$ ini berdasarkan pengalaman peneliti secara langsung, sewaktu proses pelaksanaan kampanye yang dilakukan oleh Edy Rahmayadi di kabupaten Labuhanbatu. Berjalannya kampanye ketika itu tidak bisa dilepaskan dari peran Pemuda Pancasila sebagai salah satu kelompok yang siap memenangkan pasangan calon tersebut. Mobilisasi massa kampanye didominasi oleh kader, bahkan setiap kader pun ikut serta mengajak masyarakat setempat untuk menghadiri kampanye itu.

${ }^{5}$ Dapat dilihat dalam Skripsi mahasiswa Universitas Sumatera Utara:

Muhammad Iqbal. 2017. "Peran Pemuda Pancasila dalam Mendukung Pencalonan Kepala Daerah (Studi tentang, Kemenangan Pangonal Harahap dan Andi suhaimi Dalimunthe Sebagai Bupati dan Wakil Bupati Labuhanbatu 2015)."
} 
Akan tetapi pada persoalan menetapkan pilihan pada calon gubernur, antara bupati dan wakil bupati memiliki preferensi politik yang berbeda. Dimana Pangonal Harahap selaku Bupati Kabupaten Labuhanbatu mendukung pasangan calon Djarot-Sihar yang notabene diusung partai PDI-P selaku partai yang mengusungnya menuju jabatan bupati ada pemilihan sebelumnya. Bahkan bupati tersebut menjadi salah satu tim pemenangan pasangan calon nomor urut 2. Sedangkan wakil bupati seperti paparan di atas, malah mendukung pasangan calon nomor urut $1 .^{6}$ Kenyataan ini menjadikan pertarungan pilihan politik antar pemegang kekuasaan di ranah lokal.

Hubungan klientalistik yang dibangun oleh Wakil Bupati Labuhanbatu kepada jaringan kader Pemuda Pancasila yang berada di bawah komandonya, terdapat pertukaran dalam bentuk distribusi keuntungan-keuntungan yang didapat. Sebagai ketua MPC, secara tidak langsung otoritas dan kekuasaan yang dimilikinya menjadi modal utama dalam menggerakkan dan mengatur aktivitas kadernya. Selain kepada internal kader, dia juga dapat membangun jejaring menggunakan simbol-simbol Pemuda Pancasila guna meraih dukungan dan suara untuk pasangan calon yang didukung.

Lazimnya dalam sebuah penelitian, terdapat kajian dan penelitian yang relevan dan sudah pernah dilakukan mengenai pembahasan dan tema yang akan diteliti dalam penelitian selanjutnya, guna untuk menjadi acuan awal dalam tahap perumusan dan pembahasan fokus kajian antara masing-masing penelitian. Beberapa penelitian terdahulu yang relevan tentang klientelisme yang terjadi di berbagai daerah akan dijadikan sebagai landasan awal bagi peneliti untuk melakukan penelitian selanjutnya. Pertama, penelitian yang dilakukan Rekha Adji Pratama dengan judul "Patronase, Klientelisme Pada Pilkada Serentak Kota Kendari Tahun 2017"' .

Penelitian ini melihat pengaruh dari seorang calon kepala daerah petahana pada proses pemenangan pilkada. Tulisan ini setidaknya akan menjelaskan tentang seorang politisi (Walikota Kendari) yang berusaha membangun patronase dan klientelisme dengan aparat birokrasi dan masyarakat untuk menjaga stabilitas kepemimpinannya hingga akhir jabatan, meraih keuntungan pribadi dari efek patronase dan klientelisme yang diterapkan dan agar memastikan anaknya Adriatma Dwi Putra (ADP) menang dalam pertarungan pilwali Kota Kendari 2017. Posisi Asrun sendiri sangat menguntungkan bagi anaknya yakni ADP. Besarnya peluang ADP terpilih ini tidak bisa dilepaskan dari keuntungan yang didapat oleh Asrun yang masih aktif sebagai Walikota Kendari, baik keuntungan langsung maupun tidak langsung.

\footnotetext{
${ }^{6}$ Wawancara dengan Kamal Ilham, Kepala Dinas Lingkungan Hidup Kabupaten Labuhanbatu, 24 Juni 2018 7R. A. Pratama. "Patronase, Klientelisme dan Pada Pilkada Serentak Kota Kendari Tahun 2017. JWP (Jurnal Wacana Politik), 2(1). 2017.
} 
Kedua, penelitian dari Ainur Rofieq dan Rahmat Nuryono dengan judul "Pengaruh Klientelisme Terhadap Perilaku Pemilih Masyarakat Kecamatan Sukatani Pada Pilkada Kabupaten Bekasi 2012"8. Penelitian ini dilatarbelakangi oleh keterpilihan Neneng Hasanah Yasin-Rohim Mintareja yang mengalahkan incumbent kepala daerah dan wakil kepala daerah pada Pilkada Kabupaten Bekasi tahun 2012. Dalam pemilihan kepala daerah tersebut terjadi dinamika perilaku memilih masyarakat. Diduga terjadi praktik klientelisme dalam kemenangan Neneng Hasanah Yasin tersebut. Fokus penelitian ini adalah dengan melihat perilaku memilih masyarakat di Kecamatan Sukatani yang memiliki karakteristik sebagai wilayah pertanian. Terpilihnya Neneng Hasanah Yasin, sebagai Bupati Bekasi dalam Pilkada Kabupaten Bekasi 2012 merupakan sesuatu yang baru dalam sejarah masyarakat Bekasi. Kemenangan Neneng Hasanah Yasin menjadikannya sebagai kepala daerah perempuan pertama di Kabupaten Bekasi.

Ketiga, penelitian Lesmana Rian Andhika dengan judul "Bahaya Patronase dan Klientelisme Dalam Pemilihan Kepala Desa Serentak" . Temuan empiris dari berbagai literatur yang ada berpola pada konsep patronase dan klientelisme, istilah konsep ini masih sering diperdebatkan di berbagai studi ilmu sosial. Namun di berbagai studi konsep patronase dan klientelisme lebih sering dikaji pada pemilihan skala besar seperti pemilihan kepala daerah, pemilihan anggota legislatif, dan pemilihan presiden karena melibatkan kendaraan partai politik atau partai politik pendukung pemerintah.

\section{Klientalisme Politik}

Klientelisme adalah jaringan antara orang-orang yang memiliki ikatan sosial, ekonomi dan politik yang didalamnya mengandung elemen iterasi, status inequality dan resiprokal (Tomsa\&Ufen, 2012). Kemudian, klientelisme juga adalah relasi kuasa antara patron dan klien yang bersifat personalistik, resiprositas, hierarkis dan iterasi. Maka dapat dipastikan bahwa klientelisme berbicara tentang jaringan atau relasi. Jaringan tersebut mengandung relasi kuasa yang tidak setara dimana patron memiliki kuasa penuh terhadap jaringan tersebut. Dalam kajian politik, klientelisme diartikan sebagai jaringan yang dikuasai patron untuk mengintervensi kliennya (Aspinall, 2015) ${ }^{10}$.

Dari pendapat ahli ini dapat diketahui bahwa klientelisme memiliki beberapa elemen kunci. Tiga elemen klientelisme yaitu iterasi, asimetri, dan resiprositas (Tomsa \& Ufen,

8Rofieq, A. \& Nuryono, R. Pengaruh Klientelisme terhadap Perilaku Pemilih Masyarakat Kecamatan Sukatani pada Pilkada Kabupaten Bekasi 2012. Politik Indonesia: Indonesian Political Science Review, 1(2). 2016. 105-119.

${ }^{9}$ L. R. Andhika, "Bahaya Patronase dan Klientelisme Dalam Pemilihan Kepala Desa Serentak". UNPAD (2017)

${ }^{10}$ R. A. Pratama, Patronase, Klientelisme dan Pada Pilkada Serentak Kota Kendari Tahun 2017. JWP (Jurnal Wacana Politik). 2017. 2(1). 
2012) ${ }^{11}$. Selain itu, menurut ahli lain empat komponen klientelisme yaitu personalistik, resiprositas, hirarki dan iterasi (Aspinall, 2015). Namun dari dua ahli tersebut, setidaknya dapat ditarik benang merah bahwa klientelisme memiliki empat elemen karakteristik: iterasi, asimetris, resiprositas dan personalistik.

Namun penggunaan istilah klientelisme sendiri masih kontroversial disebabkan oleh luasnya dan variatifnya pola pertukaran politik yang bisa digambarkan oleh istilah ini. Sebagaimana diuraikan lebih mendalam oleh Jonathan Hopkin $(2006)^{12}$, klientelisme merupakan sebuah bentuk pertukaran yang sifatnya personal dan biasanya dicirikan dengan adanya sejumlah kewajiban dan bahkan juga adanya hubungan kekuasaan yang tidak seimbang di antara mereka yang terlibat. Pola hubungan ini ditandai dengan aktivitasaktivitas patron yang menyediakan untuk sang klien berupa akses kepada sarana-sarana dasar subsistensi dan terbentuknya pola hubungan yang resiprokal dengan sang klien melalui aktivitas yang mengkombinasikan antara pelayanan dan penyediaan barang ekonomi.

Kadang-kadang istilah klientelisme digunakan secara bergantian dengan suatu istilah yang terkait erat dengannya, patronase. Namun demikian, Edward Aspinall \& Ward Berenschot ${ }^{13}$ lebih memilih menggunakan istilah patronase untuk merujuk secara khusus pada barang dan manfaat yang didistribusikan melalui pertukaran klientelistik. Dengan kata lain, jika klientelisme merujuk pada suatu jenis pertukaran yang khas, patronase merujuk pada apa yang dipertukarkan. Dengan demikian, mereka menggunakan istilah patronase untuk menggambarkan barang-barang material dan manfaat-manfaat lainnya yang didistribusikan oleh para politisi dengan cara yang sesuai dengan dukungan pada pemilihan umum.

Meskipun demikian, setidaknya ada dua elemen penting yang melekat dalam aktivitas klientelisme. Pertama, resiprositas (tipe pertukaran dari sebuah hubungan). Pada tipe pertukaran sebuah hubungan, dua kelompok terlibat dalam penyediaan barang dan layanan dan saling berbagi manfaat yang saling menguntungkan dalam kondisi relatif saling sukarela sehingga tindakan-tindakan klientelisme tidak bisa ditemukan dalam sistem politik yang otoriter atau model-model hubungan perbudakan dan pertuanan. Patron mempertukarkan sumberdaya (pekerjaan dan perlindungan) dengan suara, dukungan, loyalitas klien. Keduanya tersambungkan melalui jalinan kepentingan dan pertemanan. Kedua, adanya ketidaksetaraan. Ketidaksetaraan berlangsung dalam pertukaran tersebut dikarenakan sang patron memiliki beragam sumber daya sedangkan klien

\footnotetext{
${ }^{11}$ Ibid.

${ }^{12}$ Hasrul Hanif. "Politik Klientelisme Baru dan Dilema Demokratisasi di Indonesia". JSP: Jurnal Ilmu Sosial dan Ilmu Politik, 12(3). 2009. 327-351.

${ }^{13}$ Aspinall, E., \& Berenschot, W. 2019. Democracy for Sale: Pemilu, Klientelisme, dan Negara di Indonesia. Jakarta: Yayasan Pustaka Obor Indonesia.
} 
mentransformasikan pola hubungan tersebut menjadi pola vertikal, yang kemudian mensyaratkan adanya superioritas satu terhadap yang lain dalam hubungan tersebut.

Klientelisme melibatkan hubungan asimetris namun saling menguntungkan antara individu atau kelompok yang memiliki kedudukan sosio-ekonomi atau politik yang tidak setara. Tingkat ketidaksetaraan posisi mitra dalam hal asimetris ini dapat bervariasi dari kasus ke kasus dan berkurang karena sistem politik, demokrasi dan sumber daya lebih banyak didistribusikan. Analisis yang dapat dibangun di antara pola klientelisme secara empirik menjadi cerminan ada hubungan timbal balik yang saling menguntungkan. Konsekuensi logisnya adalah dukungan yang diberikan tidak murni, ada persyaratan khusus yang harus dibayar dengan pola perencanaan yang matang untuk strategi politik masa depan. Dimana ada klientelisme, peluang vote buying menjadi lebih besar. Klientelisme juga tidak lagi bisa dipersepsikan sebagai hubungan atas dasar figur panutan. Karena pola distribusi klientelisme akan menyasar masyarakat miskin dan sumber daya manusia yang rendah.

\section{METODE PENELITIAN}

Penelitian ini menggunakan metode kualitatif, penggunaan metode kualitatif bertujuan untuk memahami fenomena sosial yang mendalam dan tersembunyi antara peneliti dan fenomena yang diteliti. Penelitian kualitatif mengharuskan peneliti meleburkan diri dalam setting sosial yang ia teliti, mengamati orang-orang dalam lingkungan alami mereka, dan ikut serta dalam aktivitas mereka. Dengan metode ini, peneliti menulis catatan lapangan secara mendalam. Pengamat partisipan bergantung pada relasi yang relatif panjang dengan para informan, dan percakapan menjadi bagian tak terpisahkan dari catatan lapangan ${ }^{14}$.

Sedangkan tipe pendekatan pada penelitian ini adalah studi kasus (case study). Pendekatan ini memfokuskan pada suatu kasus atau lebih dalam fenomena sosial. Kemudian bertujuan untuk mencari rincian makna yang kompleks tentang fenomena masalah yang ada, menjelaskan bagaimana dan mengapa sebuah kasus terjadi. Studi kasus dapat menggambarkan topik-topik tertentu dan mengevaluasi sesuatu yang telah dilakukan dalam tipe deskriptif dengan menggunakan prosedur tertentu.

\section{HASIL DAN PEMBAHASAN}

\section{Klientalisme Politik Pemuda Labuhanbatu Dalam Pilkada Sumatera Utara Tahun 2018}

\footnotetext{
${ }^{14}$ Marsh, D., \& Stoker, G. 2010. Teori dan metode dalam ilmu politik. Bandung: Nusa Media.
} 
Pemuda Pancasila sebagai organisasi kemasyarakatan (ormas) terbesar di Sumatera Utara, yang secara tidak langsung memiliki kepentingan politik, pengurus wilayah Pemuda Pancasila harus berperan dalam pemilihan Gubernur Provinsi Sumatera Utara Tahun 2018. Dukungan yang diberikan Pemuda Pancasila kepada pasangan calon Edy Rahmayadi dan Musa Rajekshah pada pemilihan tersebut dilatarbelakangi berbagai hal sebagai pertimbangan. Salah satunya adalah pencalonan wakil gubernur yang didukung merupakan kader sekaligus pengurus Majelis Pimpinan Wilayah (MPW) Pemuda Pancasila Sumatera Utara. Musa Rajekshah menjabat sebagai Ketua Bidang Pengusaha dalam kepengurusan MPW Pemuda Pancasila. Pada proses pencalonan, beliau dipasangkan sebagai wakil dari Edy Rahmayadi yang memiliki latar belakang militer.

Alasan pemberian dukungan kepada pasangan Edy-Musa disebabkan adanya kader Pemuda Pancasila yang secara langsung menjadi bagian sebagai peserta kontestasi pada pemilihan gubernur. Apabila dilihat lebih mendalam, Musa Rajekshah sendiri merupakan keponakan dari Ketua MPW Pemuda Pancasila Sumatera Utara yaitu Kodrat Shah. Adanya hubungan kekeluargaan yang dimiliki Musa menjadikannya sebagai modal sosial awal yang akan menguntungkan dalam proses pemilihan tersebut.

Menanggapi hal demikian, Pemuda Pancasila di tingkat MPC Labuhanbatu melakukan rapat kerja daerah (Rakerda) untuk membahas dan mendiskusikan bentuk dukungan yang akan dilakukan pada masa-masa pencalonan, salah satunya pada saat masa kampanye. Hal ini sejalan dengan dilakukannya rapat kerja wilayah (Rakerwil) MPW PP di tingkat provinsi guna menyatakan sikap dan dukungan kepada pasangan calon Edy-Musa sebagai gubernur dan wakil gubernur. Karena Pemuda Pancasila juga merupakan organisasi yang memiliki aturan organisasi seperti halnya tata tertib administrasi yang bertujuan untuk memberikan informasi dan gambaran umum tentang sikap politik yang akan diambil dalam hal pemilihan gubernur tersebut.

Peneliti berpendapat bahwa dalam rakerda tersebut MPC Pemuda Pancasila ingin menghadirkan jajaran pengurus yang berada dibawahnya, dari tingkat Pimpinan Anak Cabang sampai kepada pengurus tingkat Anak Ranting di tingkat dusun/kelurahan. Agenda tersebut sebagai mediasi menyampaikan pandangan ketua MPC PP terkait alasan pemberian dukungan kepada pasangan calon gubernur yang didukung sehingga dapat memberikan pemahaman kepada jajaran pengurus untuk ditindak lanjuti ke seluruh kader yang berada dalam satuan organisasi Pemuda Pancasila.

Untuk menggambarkan klientelisme politik tidak bisa menghapuskan segala aspek yang menimbulkannya. Seperti contohnya, klientelisme selalu melibatkan keluarga kerabat, teman, partisipan loyalis dan juga klientelisme juga cenderung memanfaatkan partisipan sukarela tanpa adanya hubungan yang dapat menimbulkan mobilisasi partisipan. Karena sosok figur panutan juga mempengaruhi orang untuk menjadi anggota tim kampanye secara 
sukarela. Disisi lain klientelisme dalam bentuk pertukaran dukungan yang sederhana untuk keuntungan tidak berbeda dengan patronase dan vote buying. ${ }^{15}$

Dalam kasus ini, sosok panutan yang mempengaruhi pilihan dan loyalitas Pemuda Pancasila untuk memenangkan pasangan Edy-Musa pada pemilihan gubernur tidak lain adalah ketua MPC Pemuda Pancasila itu sendiri. Sosok Andi Suhaimi Dalimunthe, peneliti meyakini sebagai figur yang sangat berpengaruh dalam upaya pemenangan tersebut. Karna peneliti berpendapat bahwa pengaruh ketokohan ketua MPC Pemuda Pancasila telah terbukti dan berhasil memanfaatkan loyalitas dan militansi yang dimiliki kader Pemuda Pancasila untuk merebut kursi kepala daerah Labuhanbatu pada pemilihan bupati dan wakil bupati tahun 2015.

Andi Suhaimi Dalimunthe yang berlatar belakang seorang pengusaha mencalon sebagai wakil bupati berpasangan dengan Pangonal Harahap yang juga merupakan seorang pengusaha, berhasil mengalahkan pasangan petahana. Calon yang diusung koalisi partai PDI-P dan Golkar ini memenangkan kontestasi pilkada pada pemilihan Bupati Labuhanbatu tahun 2015 dengan diikuti lima (5) pasangan calon. Dalam salah satu penelitian skripsi, Muhammad Iqbal ${ }^{16}$ menjelaskan bahwa salah satu modal utama adalah dukungan Pemuda Pancasila sebagai organisasi masyarakat yang memiliki perjalanan politik sebagai organisasi berbasis massa yang ahli dalam melakukan mobilisasi politik sampai mempengaruhi pilihan politik pemilih yang belum menentukan pilihan pada saat hari pencoblosan.

Terlibatnya Pemuda Pancasila dalam konfigurasi politik di Labuhanbatu bukanlah hal yang baru, terlebih pada pemilihan gubernur Sumatera Utara tahun 2018. Pemuda Pancasila yang dikenal memiliki kader loyal serta militansi yang tinggi serta sering melakukan intimidasi, paksaan dengan kemampuan yang dimilikinya. Penggunan Pemuda Pancasila sebagai alat untuk mempengaruhi pemilih dan terlibat dalam melakukan aksi-aksi kampanye. Banyaknya kader-kader Pemuda Pancasila yang menduduki jabatan strategis dan beberapa kader juga memiliki sumberdaya finansial yang mencukupi yang berlatar belakang sebagai pengusaha dan pemilik modal tanah, menjadi keuntungan tersendiri bagi Ketua MPC Pemuda Pancasila saat menyatakan dukungan kepada pasangan calon gubernur Edy-Musa tahun 2018.

Sumber-sumber kekuasaan yang dimiliki tokoh dari Pemuda Pancasila di Labuhanbatu berasal dari kekuatan fisik dan keberanian untuk mempengaruhi orang lain untuk mengikuti kehendaknya. Dari kekuatan fisik itu tokoh Pemuda pancasila semakin kuat dengan memperoleh sumber daya ekonomi. Tokoh Andi Suhaimi Dalimunthe sebagai pimpinan organisasi, menggunakan Pemuda Pancasila sebagai alat untuk memobilisasi

\footnotetext{
${ }^{15}$ L. R. Andhika. Bahaya Patronase dan Klientelisme Dalam Pemilihan Kepala Desa Serentak. Jurnal UNPAD. 2017

${ }^{16}$ Muhammad Iqbal. 2017. Peran Pemuda Pancasila dalam Mendukung Pencalonan Kepala Daerah (Studi tentang, Kemenangan Pangonal Harahap dan Andi suhaimi Dalimunthe Sebagai Bupati dan Wakil Bupati Labuhanbatu 2015). Skripsi. Universitas Sumatera Utara (USU), Medan.
} 
massa dengan memberikan tekanan kepada setiap anggota untuk memilih serta mempengaruhi pemilih yang lain untuk memberikan suara kepada pasangan yang didukung.

Klientelisme politik memiliki karakteristik yang dikenal dengan istilah iterasi, yang mengandung makna adanya tindakan yang dilakukan secara berulang-ulang oleh seorang figur yang memiliki pengaruh ketokohan seperti yang dapat dilihat pada pola yang dibangun Andi Suhaimi Dalimunthe terhadap Pemuda Pancasila. Iterasi menggambarkan perilaku klientelistik yang menekankan pada aspek pengulangan pola-pola yang telah dibangun jauh sebelumnya. Meskipun klientelisme politik lebih sering didefinisikan sebagai hubungan timbal balik yang saling menguntungkan (resiprokal), akan tetapi karakteristik iterasi menjadi aspek penguat pada relasi jaringan klientelisme tersebut dalam berbentuk pengulangan distribusi jaringan personal yang sangat loyalis. Sehingga karakteristik klientelisme semacam itu dapat mengalahkan relasi jaringan yang dibangun hanya pada saat akan dilaksanakannya suatu pemilihan.

Peneliti melihat implikasi dari proses pengulangan/iterasi dalam memanfaatkan basis massa Pemuda Pancasila dalam kontestasi politik elektoral. Alur iterasi klientelisme dimulai dari upaya Pemuda Pancasila memenangkan sosok Andi Suhaimi Dalimunthe dalam pemilihan bupati Labuhanbatu pada tahun 2015, kemudian berlanjut pada pemberian dukungan kepada pasangan Edy-Musa pada pemilihan gubernur Sumatera Utara tahun 2018 sebagai tim yang dibentuk oleh Pemuda Pancasila guna memenangkan pasangan calon tersebut. Banyaknya kader yang dimiliki Pemuda Pancasila terlihat memberikan kontribusi besar pada proses kedua pemilihan kepala daerah yang secara langsung mereka ikuti sebagai kelompok pemenangan.

Kemudian dari aspek resiprositas dalam pendanaan yang diberikan Ketua MPC Pemuda Pancasila dalam upaya pemenangan pada pemilihan gubernur. Karakteristik resiprositas ini memperlihatkan adanya sumber daya finansial yang dimiliki Andi Suhaimi untuk memberikan pendanaan organisasi dalam setiap kegiatan yang dilakukan. Tipe pertukaran dari sebuah hubungan (resiprositas) hal yang paling melekat dalam praktik klientelisme politik dan hal ini dapat dilihat adanya pada aspek pendanaan yang berasal dari Ketua MPC Pemuda Pancasila yang sekaligus menjabat sebagai wakil bupati Labuhanbatu. Sehingga kedua karakteristik diatas (iterasi dan resiprositas) pada klientelisme politik Pemuda Pancasila Labuhanbatu sudah memenuhi dalam bentuk tindakan yang dilakukan dan relasi jaringan yang sudah dibangun MPC Pemuda Pancasila.

Analisis yang dapat dibangun terkait dengan pertukaran klientelistik adalah pasangan calon dapat memperoleh dukungan melalui pemberian hadiah atau kebijakan-kebijakan tertentu setelah duduk sebagai kepala daerah terpilih. Dalam praktik klientelisme politik barang-barang itu disebut dengan clientelistic goods yang merujuk pada barang-barang material atau kebijakan-kebijakan yang diberikan oleh patron untuk klien sebagai bentuk pertukaran dukungan politik. Pada proses pemenangan calon gubernur, relasi jaringan 
Pemuda Pancasila Labuhanbatu sebagai klien dan dipimpin oleh seorang wakil bupati pada saat itu, juga mendapatkan imbalan yang dikenal sebagai pertukaran dalam bentuk klientelistik.

Pertukaran yang didapatkan Andi Suhaimi Dalimunthe adalah adanya program pembangunan yang lebih intensif yang diberikan pasangan calon yang didukung ketika menang dalam pemilihan gubernur tersebut. Pertukaran yang didapat dalam bentuk program pembangunan daerah ini menggambarkan posisi sebagai wakil kepala daerah yang bertujuan untuk kelayakan infrastruktur untuk masyarakat. Dalam pustaka klientelisme politik, hadiah-hadiah semacam itu sering disebut dengan barang bersama, karena program pembangunan infrastruktur lebih memberi manfaat kepada masyarakat secara kolektif daripada hanya diberikan kepada perorangan.

\section{Klientalisme Politik Pemuda Pancasila Dalam Tinjauan Aktor}

Pada penelitian ini, posisi klien digambarkan pada Pemuda Pancasila dalam upaya pemenangan pasangan calon gubernur Sumatera Utara tahun 2018. Sehingga fokus utamanya adalah jajaran kepengurusan di tingkat MPC (Majelis Pimpinan Cabang) Pemuda Pancasila dalam analisis praktik klientelisme politik. Andi Suhaimi Dalimunthe sebagai sosok Ketua MPC dan sekaligus wakil bupati Labuhanbatu merupakan simbol dari organisasi Pemuda Pancasila yang membentuk tim pemenangan pada masa kontestasi politik berlangsung. Keberadaaan Andi Suhaimi Dalimunthe sebagai klien memperlihatkan bahwa Pemuda Pancasila melakukan aktivitas politik karena adanya hubungan timbal balik bersifat simbiosis mutualisme yang nantinya didapatkan Pemuda Pancasila dalam pemberian dukungan kepada pasangan calon gubernur.

Pemuda Pancasila sebagai domain klien utama dalam penelitian ini, dilihat dari keputusan yang diambil mengenai kepada siapa akan mendukung saat pilkada merujuk kepada satu orang yang sangat berperan dalam keputusan tersebut. Sosok yang dimaksud adalah elite Pemuda Pancasila yaitu Andi Suhaimi Dalimunthe ketua MPC Pemuda Pancasila Labuhanbatu. Andi merupakan figur sentral dalam pembuatan keputusan dari Pemuda Pancasila. Setelah memberikan deklarasi dukungan kepada pasangan Edy-Musa, Pemuda Pancasila juga melakukan mobilisasi massa untuk memenangkan pasangan tersebut. Mobilisasi yang dilakukan Pemuda Pancasila dengan mobilisasi internal seperti kader dan anggota serta organisasi-organisasi sayap seperti Sapma (satuan pelajar dan mahasiswa) Pemuda Pancasila.

Pembentukan tim pemenangan internal Pemuda Pancasila dilakukan karena Andi Suhaimi Dalimunthe beranggapan bahwa tindakan-tindakan mobilisasi yang dilakukan akan berbeda dengan tim pemenangan yang dibentuk oleh partai-partai pengusung pasangan calon gubernur. Dalam agenda mobilisasi dan sosialisasi pasangan calon kedua 
tim ini berjalan tidak beriringan, dimana tim pemenangan Pemuda Pancasila bergerak dengan agenda yang berbeda dengan tim bentukan partai. Bentuk kepengurusan sebagai $e x-$ officio tim pemenangan Pemuda Pancasila tersebar pada 9 PAC (Pimpinan Anak Cabang), dengan total 98 Ranting yang masing-masing terdiri dari 75 desa dan 23 kelurahan. Kemudian ada yang namanya Anak Ranting untuk tingkat dusun dan lingkungan yang hampir menyeluruh di tiap-tiap desa dan kelurahan.

Mobilisasi kedalam internal ini merupakan cara utama yang harus diambil oleh Pemuda Pancasila dibanding memobilisasi massa mengambang seperti masyarakat umum. Cara tokoh Pemuda Pancasila untuk memobilisasi massa internalnya adalah dengan menggunakan persuasif instruksi satu komando. Sistem satu komando memang sudah dimiliki dan dikenal melekat pada tubuh organisasi Pemuda Pancasila dalam segala instruksi agenda kegiatan organisasi. Dimana elite yang berada di tingkatan atas menginstruksikan kepada jajaran kader yang ada dibawahnya lalu diteruskan kepada anggota yang berada pada tataran akar rumput. Bentuk instruksi ini mengenai upaya yang dilakukan tim pemenangan internal Pemuda Pancasila dengan memberikan sosialisasi mengenai visi-misi dari pasangan Edy-Musa.

Suatu hal yang menarik dari mobilisasi yang dilakukan Andi Suhaimi Dalimunthe dengan adanya tindakan persuasif dan instruksi satu komando ini, juga didukung dengan pemberian rangsangan-rangsangan materi yang akan diberikan kepada kader-kader Pemuda Pancasila. Rangsangan pemberian materi sebagai imbalan yang nantinya akan didapatkan kader ini diberikan Ketua MPC Pemuda Pancasila kepada jajaran struktur kepengurusan dan juga kepada ketua-ketua organisasi sayap serta seluruh kader yang terlibat dalam tim internal bentukan Pemuda Pancasila. Materi yang diberikan dalam bentuk kesejahteraan bagi kader berupa pemberian pekerjaan, pemberian bantuan dalam bidang pendidikan dan terkadang juga pemberian sejumlah uang dengan bentuk pendanaan kegiatan organisasi pada saat proses pemilihan berlangsung. Rangsangan pemberian materi ini membentuk rasa loyalitas dan militansi yang dimiliki kader Pemuda Pancasila kepada elite yang telah memberikan materi tersebut, sehingga ketika elite memberikan instruksi untuk melakukan dukungan kepada pasangan calon gubernur yang didukung, maka kader akan ikut turut dengan instruksi diberikan.

Dalam konteks klientelisme pada hubungan patron-klien, posisi seorang patron memiliki sumber yang melebihi baik secara langsung maupun tidak langsung dari seorang klien. Posisi itu menyebabkan seorang patron mampu mempengaruhi sikap dan perilaku klien. Sebaliknya, klien mengakui dan menerima sumberdaya yang dimiliki patron sehingga bisa mempengaruhi klien, maka klien akan menerima dan mengakui pengaruh tersebut secara sadar dan sukarela. Sifat kedudukan patron-klien didasarkan atas pertukaran yang tidak seimbang (inequality) karena adanya perbedaan status antara keduanya. 
Hubungan yang tidak seimbang tersebut membuat klien merasa berhutang budi dan membalas jasa kepada patron.

Figure 1

\section{Skema Aktor Klientelisme Politik Pemuda Pancasila Pada Pemilihan Gubernur Sumatera} Utara Tahun 2018

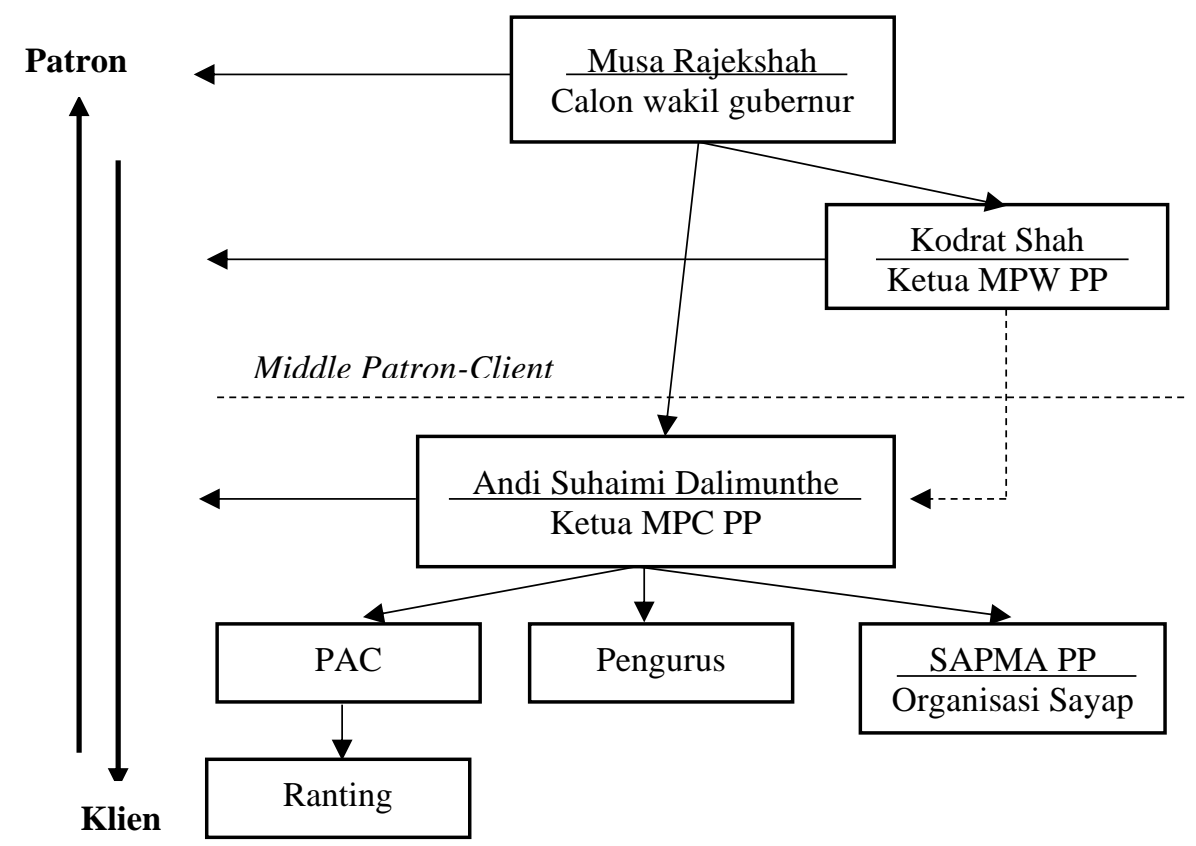

Salah satu teori yang dapat menjelaskan posisi kedudukan patron-klien dalam studi keterlibatan Pemuda Pancasila Labuhanbatu pada pemilihan gubernur Sumatera Utara tahun 2018 adalah teori James Scott tentang patron-client cluster. ${ }^{17}$ Scott menjelaskan bahwa kelompok patron-klien bisa berbentuk gugus patron-client cluster yaitu seorang patron dengan beberapa klien. Kemudian patron-klien juga bisa berbentuk gabungan dari berbagai gugus patron-klien yang dipimpin oleh seorang patron sebagai patron tertinggi (patron-client pyramid). Dibawah patron tertinggi itu, terdapat sejumlah klien yang merupakan patron kecil bagi sejumlah klien. Seorang klien dari patron tertinggi juga menjadi seorang patron bagi beberapa klien. Dalam bentuk piramid itu, ada beberapa patron kecil yang menjadi klien patron tertinggi dan mempunyai beberapa klien sendiri. ${ }^{18}$

\footnotetext{
${ }^{17}$ James C. Scott. 1972. "Patron-Client Politics and Political Change in Southeast Asia". dalam The American Political Science Review. Vo. 6. No. 1 (Mar. 1972). hal. 92.

${ }^{18}$ Muryanto Amin. 2013. Kekuasaan dan Politik Lokal (Studi tentang Peran Pemuda Pancasila dalam

Mendukung Syamsul Arifin dan Gatot Pudjonugroho sebagai Calon Gubernur dan Wakil Gubernur Provinsi Sumatera Utara Tahun 2008). Tesis. Universitas Indonesia.
} 
Pola kedudukan patron-klien yang terjadi pada studi penelitian ini dapat dilihat dari peran yang dimiliki Ketua MPC Pemuda Pancasila. Dalam struktur Pemuda Pancasila Labuhanbatu, posisi patron diisi oleh Andi Suhaimi Dalimunthe dengan jabatan ketua MPC dan sekaligus wakil bupati, kemudian disatu sisi yang lain, beliau juga berperan sebagai klien yang berada dibawah struktur kepengurusan MPW Pemuda Pancasila Sumatera Utara sebagai patron, kemudian posisi patron tertinggi nya diduduki oleh calon wakil gubernur selaku kader dan pengurus MPW Pemuda Pancasila. Oleh karena itu, dalam bentuk piramida klientelistik Pemuda Pancasila, ada beberapa patron kecil yang menjadi klien pada patron tertinggi dan mempunyai beberapa klien sendiri.

\section{Model Relasi Jaringan Pemuda Pancasila Labuhanbatu}

Hubungan yang dibangun jauh sebelum masa pemilihan calon gubernur oleh Pemuda Pancasila disebabkan kedekatan personal antara Ketua MPC dan jajaran struktural pengurus. Dimana sosok ketua MPC merawat dengan baik basis massa yang dimilikinya ini karena dianggap dapat dijadikan sebagai salah satu modal untuk ikut serta dalam konstalasi politik di Labuhanbatu. Hal ini terbukti dengan Ketua MPC mencalonkan diri sebagai wakil bupati pada perhelatan pemilihan kepala daerah Labuhanbatu tahun 2015, dengan hasil kemenangan yang diperoleh. Memperlihatkan keberhasilan membentuk jaringan relasi dengan kader-kader Pemuda Pancasila atas dasar kepentingan personalistik yang dimiliki Ketua MPC yang menjabat sebagai wakil kepala daerah. Relasi yang terjalin antara Ketua MPC dan pengurus Pemuda Pancasila merupakan ikatan hubungan saling menguntungkan. Disatu sisi, pengurus Pemuda Pancasila menginginkan akan memperoleh akses terhadap sumber-sumber daya pemerintahan di daerah (local government resources). Sementara disisi lain, Ketua MPC membutuhkan kekuatan basis massa yang dimiliki jajaran pengurus terhadap kader Pemuda Pancasila untuk mempertahankan dan memenangkan agenda pemilihan yang dirasa menghadirkan keuntungan tersendiri baginya.

Dengan demikian, hal tersebut ikut serta mewarnai kegiatan kampanye pada masa pemilihan gubernur Sumatera Utara yang diperankan oleh Pemuda Pancasila. Andi Suhaimi Dalimunthe sebagai ketua tim sukses bentukan partai pengusung, memiliki kewenangan untuk mengatur segala aktivitas yang dilakukan untuk pemenangan pasangan calon gubernur. Sedangkan posisi Andi yang menjabat sebagai Ketua MPC Pemuda Pancasila memberikan konsentrasi kekuasaannya di dalam tim pemenangan internal yang dibentuk melalui jajaran pengurus Pemuda Pancasila. Sehingga keterlibatan Pemuda Pancasila memperlihatkan intensitas yang tinggi terhadap proses pemenangan tersebut.

Pemanfaatan relasi hubungan ini juga berlanjut pada keterlibatan jajaran pemerintahan desa yang diisi oleh kader-kader Pemuda Pancasila sebagai kepala desa untuk ikut serta memenangkan perolehan suara serta menjamin pilihan masyarakat desa tersebut bermuara kepada pasangan calon yang didukung Pemuda Pancasila. Pada proses 
pemenangan, kepala desa yang juga kader Pemuda Pancasila menjadi ketua tim pemenangan internal. Pemanfaatan keterlibatan kepala desa pada tim pemenangan Pemuda Pancasila ini memiliki peran dalam perolehan suara yang didapat pasangan calon gubernur. Dengan adanya keterlibatan jajaran kepala desa, memudahkan tim pemenangan Pemuda Pancasila untuk melakukan konsolidasi terhadap jajaran perangkat-perangkat yang berada di desa-desa.

Pola relasi hubungan klientelistik seperti penjelasan di atas, menyebabkan munculnya jejaring pemilih dikalangan masyarakat desa yang dipengaruhi sosok kepala desa sebagai bagian dari tim pemenangan. Dalam artian bahwa pengaruh kepala desa semacam itu terhadap masyarakat sebagai pemilih sebagian besar didasarkan pada kapasitas mereka (kepala desa) dalam memanfaatkan jabatan untuk kepentingan agenda politik organisasi dalam mendukung dan memenangkan pasangan calon gubernur.

\section{Bentuk Pertukaran Klientalistik Pemuda Pancasila}

\section{Pendanaan Tim Pemenangan Internal}

Setelah Majelis Pimpinan Cabang Pemuda Pancasila Labuhanbatu membentuk tim pemenangan internal untuk mendukung calon gubernur, tugas utamanya adalah membantu kegiatan tim sukses bentukan partai koalisi yang juga diketuai oleh Ketua MPC Pemuda Pancasila. Pembentukan tim pemenangan internal Pemuda Pancasila lebih didasarkan agar dapat menjaga konsolidasi internal organisasi berjalan sesuai kesepakatan yang telah diputuskan dalam rapat kerja daerah pengurus cabang. Agenda pemenangan yang dilakukan tim internal Pemuda Pancasila setidaknya berjalan seiring program pemenangan tim sukses partai koalisi, seperti peran pengawalan saat kampanye dilaksanakan baik yang dihadiri pasangan calon maupun kampanye yang dilakukan tanpa adanya pasangan calon yang datang.

Akan tetapi perihal pembiayaan yang didapatkan tim pemenangan internal Pemuda Pancasila berbeda dengan tim sukses partai koalisi. Pendanaan tim internal Pemuda Pancasila untuk melaksanakan agenda kampanye dan pemenangan lainnya didapatkan dari pemberian Ketua MPC Labuhanbatu. Peneliti melihat bahwa pemberian dana untuk tim internal Pemuda Pancasila berasal dari keuangan Ketua MPC Labuhanbatu. Selaku ketua, Andi Suhaimi Dalimunthe menjadi penanggung jawab akan ketersediaan dana untuk biaya pelaksanaan kegiatan pemenangan. Sehingga tim internal Pemuda Pancasila dapat berjalan seperti yang telah ditentukan dalam melaksanakan agenda kampanye. Pemberian dana ini didasari atas pemberian personal Ketua MPC yang bersumber dari keuangan organisasi dan tidak adanya aliran dana yang didapatkan dari tim sukses partai koalisi. Karena pembiayaan tim sukses partai koalisi didapatkan dari partai-partai pengusung calon gubernur yang juga diterima oleh Andi Suhaimi Dalimunthe sebagai ketua tim sukses partai koalisi. 
Pengadaan logistik yang dibutuhkan sepanjang masa kampanye berlangsung, juga tidak terlepas dari sumber keuangan yang dimiliki organisasi. Sumber keuangan organisasi berasal dari pemberian Ketua MPC dan sumber dana lainnya seperti pemberian seniorsenior serta simpatisan Pemuda Pancasila yang berasal dari berbagai kalangan. Kemudian dana yang diterima tim internal tidak diminta kepada pasangan calon gubernur yang didukung. Karena Para tokoh senior dan pengurus Pemuda Pancasila dalam hal ini mengedepankan komitmen dalam upaya pemenangan tanpa mengharapkan pemberian dana dari calon gubernur yang didukung.

Setelah berjalannya masa-masa kampanye yang dilakukan, sampai kepada hari pemilihan berlangsung, peran tim internal juga membentuk saksi-saksi pada saat penghitungan suara dilaksanakan. Pembentukan saksi-saksi yang berada di TPS ini menjadi bagian dari upaya pemenangan yang dilakukan tim internal Pemuda Pancasila. Distribusi saksi yang dilakukan tim internal ini berasal dari kalangan kader-kader Pemuda Pancasila. Pelimpahan tugas ini diberikan karena mengingat Pemuda Pancasila memiliki kader-kader sampai ke seluruh desa yang ada. Sumberdaya kader ini dimanfaatkan juga sebagai jaringan untuk memperoleh suara pada masing-masing TPS yang menjadi wilayah kerja saksi yang ditunjuk. Setidaknya, peneliti melihat bahwa pemanfaatan terhadap kader yang menjadi saksi juga menjadi jaminan adanya suara yang keluar pada TPS yang berada di desa tersebut.

Biaya yang dikeluarkan untuk membayar saksi-saksi yang dibentuk tim internal ini juga berasal dari pemberian Ketua MPC Pemuda Pancasila yang sekaligus sebagai ketua tim sukses partai koalisi pendukung pasangan calon gubernur Edy-Musa. Dalam hal ini, pembiayaan saksi ditujukan juga sebagai saksi dari tim sukses partai, yang kemudian dana untuk biaya pembayaran saksi diperoleh dari partai-partai koalisi.

\section{Penerimaan Dana Hibah}

Pertukaran klientelistik selanjutnya yang didapatkan Pemuda Pancasila adalah dana hibah. Pemberian dana hibah ini berdasarkan anggaran pemerintah Kabupaten Labuhanbatu yang dialokasikan untuk organisasi kemasyarakatan yang berada di dalam teritori nya. Adanya pemberian dana hibah ini didapatkan Pemuda Pancasila setelah perhelatan pemilihan gubernur Sumatera Utara tahun 2018 selesai. Hal ini sudah menjadi karakteristik pertukaran klientelistik yang bersifat jangka panjang. Dimana pemberian dana hibah ini dapat dikategorikan sebagai hadiah yang diberikan patron terhadap apa yang sudah dilakukan Pemuda Pancasila dalam upaya pemenangan pasangan calon gubernur yang didukung.

Dana hibah yang diterima Pemuda Pancasila ini didapat setelah Andi Suhaimi Dalimunthe menjabat sebagai Plt (pelaksana tugas) Bupati Labuhanbatu. Kondisi ini disebabkan pasca terjadinya OTT (operasi tangkap tangan) kasus korupsi Bupati 
Labuhanbatu, yaitu Pangonal Harahap. Penangkapan bupati akibat tersandung kasus korupsi terjadi setelah pemilihan gubernur selesai terlaksana, tepatnya pada bulan Juli tahun 2018. Sebelumnya, pada masa Andi Suhaimi Dalimunthe masih menjabat sebagai wakil bupati, Pemuda Pancasila tidaklah mendapatkan dana hibah yang berasal dari anggaran APBD kabupaten.

Peneliti melihat adanya indikasi bahwa dana hibah yang disalurkan sebelumnya tidak ada dialokasikan untuk Pemuda Pancasila. Sehingga hal ini memperlihatkan benturan kepentingan antara bupati dan wakilnya terhadap distribusi penyaluran dana hibah tersebut. Akan tetapi, pemberian dana hibah yang diterima Pemuda Pancasila pada saat Ketua MPC menjabat sebagai Plt Bupati sebagai transaksional pertukaran klientelistik terhadap keterlibatan dalam upaya pemenangan pada masa pemilihan gubernur.

Gambaran mengenai penggunaan dana hibah yang diterima Pemuda Pancasila. Dana tersebut dijadikan sebagai keuangan organisasi yang nantinya akan digunakan untuk pendanaan kegiatan-kegiatan yang akan dilaksanakan. Sebelumnya, penggunaan proposal dana kegiatan yang dilakukan Pemuda Pancasila seringkali mewarnai setiap akan melaksanakan agenda organisasi. Karena sumber pendanaan organisasi ini juga berasal dari sumbangan-sumbangan yang diterima melalui pengajuan proposal dana kegiatan. Akan tetapi, melalui dana hibah yang telah diterima selama dua tahun terakhir, yang mana Pemuda Pancasila merupakan penerima dana hibah terbesar di antara ormas-ormas lainnya, dapat meminimalisir penggunaan proposal dana kegiatan.

\section{Pemberian Bantuan yang Bersifat Personal}

Pertukaran dalam politik klientelistik sering melibatkan manfaat yang diberikan secara pribadi melalui sumberdaya yang dimiliki patron kepada klien, kemudian didistribusikan atas dasar kebutuhan. Pemberian ini sering terlihat dalam bentuk pemberian bantuan, uang tunai, pengadaan lapangan pekerjaan dan program yang bersumber dari kebijakan pemerintah. Tujuannya adalah untuk dapat mengidentifikasi para penerima manfaat berdasarkan kesetian mereka pada patron yang memberikan atau dalam berdasarkan pemberian suara pemilih sebagai penerima manfaat menjelang pemilihan umum.

Pemberian manfaat ini juga terlihat dalam praktik klientelisme politik yang dilakukan oleh Wakil Bupati Labuhanbatu, dengan adanya pemberian berupa bantuan uang tunai dan memberikan pekerjaan bagi anggota Pemuda Pancasila dengan tujuan agar dapat meningkatkan taraf hidup anggota-anggota nya. Pemberian bantuan yang dilakukan Wakil Bupati kepada anggota Pemuda Pancasila semenjak dirinya menjabat. Kebanyakan pemberian bantuan tersebut diberikan secara perorangan yang meminta secara langsung kepadanya. Pertukaran klientelistik dalam bentuk ini sering kali diberikan jauh sebelum pemilihan gubernur Sumatera Utara tahun 2018 berlangsung. 
Tindakan ini dilakukan supaya dapat merawat sebuah hubungan yang selama ini sudah dibangun dan untuk mempertahankan hubungan klientelistik untuk jangka waktu yang lebih panjang baik setelah maupun sebelum berlangsungnya pemilihan umum. Dalam konteks ini, anggota Pemuda Pancasila yang menerima pemberian manfaat dari Ketua MPC, dipengaruhi oleh perasaan kewajiban untuk membalas budi dan rasa terima kasih yang tertanam melalui interaksi pemberian manfaat tersebut. Kemudian perasaan kewajiban dan rasa terima kasih ini dapat diandalkan Ketua MPC ketika butuh akan bantuan dalam menghadapi kontestasi politik.

\section{KESIMPULAN}

Pada proses pemenangan calon gubernur, relasi jaringan Pemuda Pancasila Labuhanbatu sebagai klien dan dipimpin oleh seorang wakil bupati pada saat itu yang sekaligus sebagai Ketua MPC Pemuda Pancasila, juga mendapatkan imbalan yang dikenal sebagai pertukaran dalam bentuk klientelistik. Rangsangan pemberian materi sebagai imbalan yang nantinya akan didapatkan kader ini diberikan Ketua MPC Pemuda Pancasila kepada jajaran struktur kepengurusan dan juga kepada ketua-ketua organisasi sayap serta seluruh kader yang terlibat dalam tim internal bentukan Pemuda Pancasila. Materi yang diberikan dalam bentuk kesejahteraan bagi kader berupa pemberian pekerjaan, pemberian bantuan dalam bidang pendidikan dan terkadang juga pemberian sejumlah uang dengan bentuk pendanaan kegiatan organisasi pada saat proses pemilihan berlangsung. Rangsangan pemberian materi ini membentuk rasa loyalitas dan militansi yang dimiliki kader Pemuda Pancasila kepada elite yang telah memberikan materi tersebut, sehingga ketika elite memberikan instruksi untuk melakukan dukungan kepada pasangan calon gubernur yang didukung, maka kader akan ikut turut dengan instruksi diberikan.

Pemanfaatan relasi hubungan ini juga berlanjut pada keterlibatan jajaran pemerintahan desa yang diisi oleh kader-kader Pemuda Pancasila sebagai kepala desa untuk ikut serta memenangkan perolehan suara serta menjamin pilihan masyarakat desa tersebut bermuara kepada pasangan calon yang didukung Pemuda Pancasila. Pada proses pemenangan, kepala desa yang juga kader Pemuda Pancasila menjadi ketua tim pemenangan internal. Pola relasi hubungan klientelistik seperti ini, menyebabkan munculnya jejaring pemilih dikalangan masyarakat desa yang dipengaruhi sosok kepala desa sebagai bagian dari tim pemenangan.

Pendanaan tim internal Pemuda Pancasila untuk melaksanakan agenda kampanye dan pemenangan lainnya didapatkan dari pemberian Ketua MPC Labuhanbatu. pemberian dana untuk tim internal Pemuda Pancasila berasal dari keuangan Ketua MPC Labuhanbatu. Selaku ketua, Andi Suhaimi Dalimunthe menjadi penanggung jawab akan ketersediaan dana untuk biaya pelaksanaan kegiatan pemenangan. Sehingga tim internal Pemuda 
Pancasila dapat berjalan seperti yang telah ditentukan dalam melaksanakan agenda kampanye. Pemberian dana ini didasari atas pemberian personal Ketua MPC yang bersumber dari keuangan organisasi dan tidak adanya aliran dana yang didapatkan dari tim sukses partai koalisi.

Pertukaran klientelistik juga didapatkan Pemuda Pancasila setelah pemilihan gubernur selesai. Pemberian dana hibah yang diterima Pemuda Pancasila melalui anggaran APBD Kabupaten Labuhanbatu, diberikan Plt Bupati yang pada sebelumnya tidak pernah didapatkan. Adanya pemberian dana hibah ini, bertujuan untuk dijadikan keuangan organisasi sehingga dapat menggerakkan roda organisasi dalam menjalankan agendaagenda kegiatan. Pemuda Pancasila menerima dana hibah terbesar di antara ormas-ormas yang ada di lingkup Kabupaten Labuhanbatu. Kemudian pemberian manfaat klientelistik seperti pemberian bantuan, uang tunai dan pengadaan pemberian lapangan pekerjaan yang bersifat personal juga diterima anggota-anggota Pemuda Pancasila.

\section{DAFTAR PUSTAKA}

\section{Buku :}

Afandi, Eka Kurniasari. 2016. "Faksionalisasi Ormas Pemuda Pancasila Dalam Tim Sukses Prabowo-Hatta di Pilpres Tahun 2014”. Jurnal Politik Muda. Vol 5.

Amin, Muryanto. 2013. Kekuasaan dan Politik Lokal (Studi Tentang Peran Pemuda Pancasila Dalam Mendukung Syamsul Arifin dan Gatot Pudjonugroho Sebagai Calon Gubernur dan Wakil Gubernur Provinsi Sumatera Utara Periode 2008-2013. Disertasi. Universitas Indonesia

Andhika, L. R. 2017. "Bahaya Patronase dan Klientelisme Dalam Pemilihan Kepala Desa Serentak". Jurnal UNPAD.

Aspinall, E., \& Berenschot, W. 2019. Democracy for Sale: Pemilu, Klientelisme, dan Negara di Indonesia. Cornell University Press.

Aspinall, E., \& Sukmajati, M. 2015. Politik Uang di Indonesia. Yogyakarta. PolGov.

Berenschot, W. 2018. The Political Economy of Clientelism: a Comparative Study of Indonesia's Patronage Democracy. Comparative Political Studies, 51(12), 15631593.

Fariz, M. W. 2017. "Politik Balas Budi: Hubungan Pemuda Pancasila dan Demokrat dalam Mobilisasi Massa Pada Pilkada Surabaya tahun 2015”. Jurnal Politik Muda, 6(2). 
Halim, A. 2014. "Politik lokal: pola, aktor \& alur dramatikalnya: perspektif teori Powercube, modal dan panggung”. Lembaga Pengkajian Pembangunan Bangsa $(L P 2 B)$.

Hanif, Hasrul. 2009. "Politik Klientelisme Baru dan Dilema Demokratisasi di Indonesia." JSP: Jurnal Ilmu Sosial dan Ilmu Politik. 12.(3): 327-351.

Iqbal, Muhammad. 2017. "Peran Pemuda Pancasila dalam Mendukung Pencalonan Kepala Daerah (Studi tentang, Kemenangan Pangonal Harahap dan Andi suhaimi Dalimunthe Sebagai Bupati dan Wakil Bupati Labuhanbatu 2015)". Skripsi. Medan: Fakultas Ilmu Sosial dan Ilmu Politik Universitas Sumatera Utara.

Karina, N. 2008. Dinamika Sosial Politik Organisasi Pemuda Pancasila Sumatera Utara. Tesis. Universitas Sumatera Utara (USU)

Marsh, D., \& Stoker, G. 2010. Teori dan metode dalam ilmu politik. Bandung: Nusa Media.

Nur Ramadhan, M. \& Berlianto, J. D. 2019. "Klientelisme Sebagai Perilaku Koruptif dan Demokrasi Banal”. Jurnal Antikorupsi INTEGRITAS, 5(1): 2615-7977. 169-180.

Pratama, R. A. 2017. "Patronase, Klientelisme dan Pada Pilkada Serentak Kota Kendari Tahun 2017. JWP (Jurnal Wacana Politik), 2(1).

Robert K. Yin. 2005. Studi Kasus Design \& Metode. Jakarta: Rajawali Pers.

Rofieq, A. \& Nuryono, R. 2016. "Pengaruh Klientelisme terhadap Perilaku Pemilih Masyarakat Kecamatan Sukatani pada Pilkada Kabupaten Bekasi 2012". Politik Indonesia: Indonesian Political Science Review, 1(2). 105-119.

Scott, James C. 1972. "Patron-Client Politics and Political Change in Southeast Asia". dalam The American Political Science Review. Vo. 6. No. 1 (Mar. 1972).

Sugiyono. 2012. Metode Penelitian Kuantitatif Kualitatif dan R\&D. Bandung: Alfabeta. 